\title{
Aspects Regarding the In vitro Propagation of 'Royal Gala' Apple Cultivar
}

\author{
Alexandru FIRA ${ }^{1}$, Manuela SIMU ${ }^{1 *}$, Bianca VLAICU ${ }^{1}$, Doina CLAPA ${ }^{1}$ \\ 1 In Vitro Culture Laboratory, Fruit Research Station Cluj, Horticultorilor 5, Cluj-Napoca, Romania \\ *)corresponding author, e-mail: manuelacarmenm@gmail.com \\ BulletinUASVM Horticulture 72(2) / 2015 \\ Print ISSN 1843-5254, Electronic ISSN 1843-5394 \\ DOI:10.15835/buasvmcn-hort:11531
}

\begin{abstract}
Apple cultivar 'Royal Gala' was multiplied in vitro on starch-gelled MS media supplemented with $0.7 \mathrm{mg} / \mathrm{l}$ BAP, which provided intense proliferation of axillary shoots. In order to test the influence of gelling agents upon proliferation rate in this apple cultivar, modified MS media were used, supplemented with $0.7 \mathrm{mg} / \mathrm{l}$ BAP and five types gelling agents: fibrous agar, $6.8 \mathrm{~g} / \mathrm{l}$; Phytagel + starch, respectively $0.5+50 \mathrm{~g} / \mathrm{l}$; guar gum, $20 \mathrm{~g} / \mathrm{l}$; Psyllium husk, $15 \mathrm{~g} / \mathrm{l}$; Phytagel at $2.2 \mathrm{~g} / \mathrm{l}$. The highest proliferation rate, $13.44 \pm 1.22$ was obtained when the media was gelling with the mixture of Phytagel + starch. By using ex vitro rooting and acclimatization in floating perlite, the rooting percentages were between $99.45 \%$ and $93.92 \%$, depending on the culture media used in the multiplication stage, from which the axillary shoots were harvested.
\end{abstract}

Keywords: apple, ex vitro rooting, floating perlite, gelling agent, meta-topolin.

\footnotetext{
Abbreviations:

IBA - indole-3-butyric acid

BAP - 6-benzilaminopurine

$\mathrm{GA}_{3}$ - gibberellic acid

MS - Murashige and Skoog Media (Murashige and

Skoog, 1962)

MSm - modified MS medium

MSa - modified MS medium, gelled with Plant Agar

MSs - modified MS medium, gelled with wheat

starch

PGR - plant growth regulator

mT - meta-topoline or meta-hydroxy-benzyladenin

REM - root elongation medium

RIM - root induction medium
}

\section{INTRODUCTION}

Apple (Malus domestica Borkh) is included in Family Rosaceae, subfamiy Pomoideae and is propagated by grafting in specialized nurseries. Additionally, research regarding apple in vitro propagation proves that this propagation method could be applied to this species, in rootstocks as well as in graft material (Dobránszky and da Silva, 2010).

The studies regarding the initiation of apple in vitro cultures were focused on establishing the optimal period for harvesting explants, using meristems from apical and axillary buds; the optimal nutritive media proved to be modified MS variants containing lower concentrations of ammonium nitrate, supplemented with BAP, IBA and GA3 (Mert and Soylu, 2010). For explant disinfection, several substances were used: mercuric chloride, natrium hypochlorite, ethyl alcohol at $70 \%$ concentration (Mert and Soylu, 2010; Amiril and Elahinia, 2011; Soni et al., 2011).

In the in vitro multiplication stage, various Murashige \& Skoog 1962 (MS) media variants were used, supplemented with various concentrations of BAP, IBA and GA3 (Mert and Soylu, 2010; Amiril and Elahinia, 2011; Soni et al., 2011). The influence of the number of subcultures upon in vitro proliferation was also studied and it was found that in the second and third subcultures 
the number of axillary shoots/explant greatly increased, being a few times higher than in the first subculture (Dalal et al., 2006).

In some apple genotypes in vitro rooting is problematic, as the rooting percentages are low. The problem was approached in various ways. Various sugars were tested in the rooting stage, where sucrose gave the best results (Reza et al., 2009); some authors obtained good results with simple protocols, MS media with auxins (Awan et al., 1990), others had positive results using longitudinal incisions in the basal part of the microcuttings (Puente and Marín 1992). Using media with salts' concentration diluted to $1 / 2$ in the in vitro rooting stage also stimulated rhizogenesis (Amiril and Elahinia, 2011). In vitro rooting on MS basal media supplemented with $0.5 \mathrm{mg} / \mathrm{l}$ IBA gave various rooting percentages depending on the genotype; relatively high in rootstock MM 106 (over $70 \%$ ), followed by M9 (over $60 \%$ ) and the lowest percentages in MM 111, under $50 \%$ (Mert and Soylu, 2010).

Some researchers used two stages for apple in vitro rooting, the first stage consisting in cultures on high concentrations of auxins and the second stage, cultures on media lacking growth regulators (Soni et al., 2011; Dalal et al., 2006; Kereša et al., 2012).

Information regarding the direct ex vitro rooting of apple shoots obtained in the multiplication stage (with bypassing the in vitro rooting stage) is scarce in scientific literature. There are some reports regarding direct ex vitro rooting just in some apple rootstock varieties. For example, in apple rootstock 'Marubakaido' the shoots treated with IBA were successfully rooted ex vitro in a mixture of ultisoil and carbonized rice husk (Maciel et al., 2002), whereas in rootstock 'M9' the shoots were rooted in a mixture of vermiculite and carbonized rice husks (Pedrotti and Voltolini, 2001); in both cases the rooting percentages were over $80 \%$. Isutsa et al. (1998) obtained good results regarding ex vitro rooting in high humidity and high $\mathrm{CO}_{2}$ concentrations. The plants obtained by ex vitro rooting were of superior quality as compared to the plants rooted in vitro.

Magyar-Tábori et al. (2001) cultured shoots of 'Royal Gala' for 1 week in liquid RIM with $3 \mathrm{mg} / \mathrm{l}$ IBA and then half of the shoots were transferred to solid REM while the other half were planted into
Jiffy-7® pellets. In vitro rooting was $100 \%$ and all plants survived after acclimatization. When shoots were planted after the induction phase directly into Jiffy-7® they were less vigorous but the rate of survival was nearly the same $(96 \%)$.

The main goal of our research was to test the direct ex vitro rooting of 'Royal Gala' apple shoots by the floating perlite method, which is a radically new, simple and efficient technique (Clapa et al., 2013). The elimination of the in vitro rooting stage from the technological process would simplify and increase the efficiency of apple micropropagation protocols. Another objective was to increase the effectiveness of the in vitro multiplication stage in apple cultivar 'Royal Gala' by using simple media, with low concentrations of cytokinins and alternative, non-conventional gelling agents.

\section{MATERIALS AND METHODS}

For the improvement of apple in vitro multiplication and ex vitro rooting and acclimatization stages, experiments were carried out at the Research Institute Nyiregyháza in Hungary as well as at the Fruit Research Station Cluj in Cluj-Napoca, Romania, in the standard culture conditions available in the in vitro culture laboratories in these two locations.

The experiments regarding the in vitro multiplication of Malus domestica cultivar 'Royal Gala' were carried out at the Research Institute Nyiregyháza. The culture conditions were: temperature $23 \pm 3{ }^{\circ} \mathrm{C}$, 16-hour photoperiod, 5500 Lux light intensity; lighting was ensured by cold white fluorescent tubes installed vertically, parallel with the culture vessels.

At the Fruit Research Station Cluj the culture conditions were: temperature of $23 \pm 3{ }^{\circ} \mathrm{C}, 16$ hour photoperiod, $2400 \mathrm{Lux}(36 \mu \mathrm{mol} \mathrm{m}-2 \mathrm{~s}-1)$ light intensity and lighting was provided by Philips fluorescent tubes installed horizontally above each shelf containing the culture vessels.

The culture vessels consisted of $720 \mathrm{ml}$ glass jars with vented caps equipped with filters; the vessels contained $100 \mathrm{ml}$ of media/vessel.

The culture media in which the stock cultures were kept in the multiplication stage consisted on MSm gelled with Plant Agar (Duchefa Biochemie BV, the Netherlands) or wheat starch (Compania Indiilor Orientale SRL) (Tab. 1); the growth regulators were BAP or $\mathrm{mT}$. All the components were added to the media before autoclavation. 
The $\mathrm{pH}$ of the media was adjusted before adding the gelling agents. For preparing the culture media we used stock solutions of macronutrients, micronutrients, vitamins, growth regulators and the carbon source was commercial crystal sugar. The media were sterilized at $121^{\circ} \mathrm{C}$ for 20 minutes the media gelled with agar and 30 minutes for the media gelled with starch.

In the in vitro multiplication stage microcuttings consisting of $2 \mathrm{~cm}$ long shoot fragments containing 4-5 nodes were used. The leaves exceeding $1 \mathrm{~cm}$ in length were cut off. Five microcuttings/culture vessels were used. The explants were inserted in oblique position into the culture media, in such a way that 2/3-3/4 of their basal part was immersed in the media, in order to achieve good contact between the explants and the media. The multiplication cycles were of 2 months.

After carrying out the multiplication cycles at the Research Institute Nyiregyháza, the axillary shoots regenerated in the multiplication stage were excised and packed into $500-\mathrm{ml}$ capped plastic food boxes. In order to prevent the desiccation of the shoots, a layer of $1 \mathrm{~cm}$ of deionized water was introduced to the bottom of the boxes. The plant material packed in this way was transported to the Fruit research station Cluj, where it was stored in a cold room at the temperature of $+4^{\circ} \mathrm{C}$ for 7 days, after which the shoots were planted into floating perlite beds.

The influence of alternative gelling agents upon in vitro multiplication in apple cultivar 'Royal Gala'

For testing the influence of gelling agents in the multiplication stage in apple cultivar 'Royal Gala', MSm basal culture media were used (Tab. 1) supplemented with $0.7 \mathrm{mg} / \mathrm{l}$ BAP. Five gelling agents were tested, in the concentrations previously tested in other species and considered as optimal concentrations for gelling culture media (Tab. 2).

The reference (control) treatment was considered to be the one where fibrous agar was used.

Totally, five repetitions per treatment were investigated, each repetition consisting of a culture vessel with 5 plantlets/treatment, in total 25 plantlets/treatment.

Tab. 1. The composition of basal culture media used for apple in vitro culture

\begin{tabular}{cccc}
\hline \multicolumn{2}{c}{ Components } & \multicolumn{2}{c}{ Concentration } \\
\hline & MSm & MSs & MSa \\
\hline MS salts & full & full & full \\
\hline Myo-inositol & $100 \mathrm{mg} / \mathrm{l}$ & $100 \mathrm{mg} / \mathrm{l}$ & $100 \mathrm{mg} / \mathrm{l}$ \\
\hline Vitamin B1 & $1 \mathrm{mg} / \mathrm{l}$ & $1 \mathrm{mg} / \mathrm{l}$ & $1 \mathrm{mg} / \mathrm{l}$ \\
\hline Vitamin B6 & $0.5 \mathrm{mg} / \mathrm{l}$ & $0.5 \mathrm{mg} / \mathrm{l}$ & $0.5 \mathrm{mg} / \mathrm{l}$ \\
\hline Nicotinic acid & $0.5 \mathrm{mg} / \mathrm{l}$ & $0.5 \mathrm{mg} / \mathrm{l}$ & $0.5 \mathrm{mg} / \mathrm{l}$ \\
\hline Sugar & $30 \mathrm{~g} / \mathrm{l}$ & $30 \mathrm{~g} / \mathrm{l}$ & $30 \mathrm{~g} / \mathrm{l}$ \\
\hline Plant Agar & \multicolumn{4}{c}{-} & $3 \mathrm{~g} / \mathrm{l}$ \\
\hline Wheat starch & \multicolumn{2}{c}{$50 \mathrm{~g} / \mathrm{l}$}
\end{tabular}

Tab. 2. The alternative gelling agents used in the in vitro multiplication stage in apple cultivar 'Royal Gala'

\begin{tabular}{cc}
\hline Treatment & Concentration (g/litre of media) \\
\hline Fibrous agar, microbiology grade & 6.8 \\
\hline Phytagel + wheat starch & $0.5 \pm 50$, respectively \\
\hline Guar gum & 20 \\
\hline Psyllium husk (Isubgol) & 15 \\
\hline Phytagel & 2.2 \\
\hline
\end{tabular}


The influence of meta-topolin upon the in vitro multiplication of apple cultivar 'Royal Gala'

The culture media consisted of MSs with two different concentrations of $\mathrm{mT}$ : $0.7 \mathrm{mg} / \mathrm{l}$, respectively $1 \mathrm{mg} / \mathrm{l}$.

Four repetitions per treatment were investigated, each repetition consisting of a culture vessel with 5 plantlets/treatment, in total 20 plantlets/ treatment. The culture period was 2 months (60 days).

\section{Direct ex vitro rooting}

The vessels used for ex vitro rooting and acclimatization were 8-liter plastic tubs. In order to make the floating perlite bed, 5 liters of potable water from the municipal network in Cluj were used (Tab. 3), upon which 5 liters of perlite were added slowly and leveled by hand, in such a way that the layer should be as even as possible.
The shoots were planted into the floating perlite layer in such a way that 2/3-1/2 of their basal part should be inserted into the layer of perlite. As a means of partial protection against excessive sunlight and air currents, the tubs were covered with caps consisting of plastic trays: 4.5 liter Multi Purpose Tub no. 1 from Demirel Plastik (www.hobby-life.com). One layer of paper was put onto these caps. The caps were maintained for seven days and then removed.

Acclimatization was carried out in the greenhouse, in May and June. The greenhouse was protected with two layers of green shading net.

No growth regulators were used for ex vitro rooting.

From each treatment, random samples of 10 plants each were investigated, in order to establish the mean length of root clumps and the number of roots/plant.

Tab. 3. The physico-chemical characteristics of the potable water at the Gilău Processing Station in Cluj, Romania (04.06.2012)

\begin{tabular}{|c|c|c|c|c|c|}
\hline No. & Parameters analyzed & $\begin{array}{l}\text { Measurement } \\
\text { units }\end{array}$ & Values & $\begin{array}{l}\text { Limits according to } \\
\text { Law } 458 / 2002 \\
\text { and } 311 / 2004\end{array}$ & Analysis methods \\
\hline \multirow[t]{20}{*}{1} & Turbidity & NTU & 0.69 & $£ 5$ & SR EN ISO $7027 / 2001$ \\
\hline & $\mathrm{pH}$ & unit. $\mathrm{pH}$ & $7.30(20.3)$ & ${ }^{3} 6.5 £ 9.5$ & SR ISO $10523 / 2009$ \\
\hline & Free residual chlorine & $\mathrm{mg} / \mathrm{l}$ & 0.98 & 0.5 & SR EN 7393-1/ 2002 \\
\hline & Chlorides & $\mathrm{mg} / \mathrm{l}$ & 3.68 & 250 & SR ISO 9297/ 2001 \\
\hline & Permanganate index & $\mathrm{mg}[0] / \mathrm{l}$ & 1.48 & 5 & SR EN ISO 8467/ 2001 \\
\hline & Ammonium & $\mathrm{mg} / \mathrm{l}$ & SLD(LD=0.03) & 0.5 & SR ISO 7150-1/ 2001 \\
\hline & Nitrites & $\mathrm{mg} / \mathrm{l}$ & SLD(LD $=0.02)$ & 0.5 & SR EN 26777/ 2002 \\
\hline & Nitrates & $\mathrm{mg} / \mathrm{l}$ & 2.86 & 50 & SR ISO 7890-3/ 2000 \\
\hline & Conductivitaty & $\mu \mathrm{S} / \mathrm{cm}$ & 87.1 & $<2500$ & SR EN 27888/97 \\
\hline & $\begin{array}{l}{ }^{*} \text { Total dissolved } \\
\text { substances }\end{array}$ & $\mathrm{mg} / \mathrm{l}$ & 52 & - & SR EN 27888/97 \\
\hline & Hardness & ${ }^{\circ} \mathrm{G}$ & 2.46 & ${ }^{3} 5$ & SR ISO 6059/2008 \\
\hline & Calcium & $\mathrm{mg} / \mathrm{l}$ & 11.98 & - & SR ISO 6058/2008 \\
\hline & ${ }^{*}$ Magnesium & $\mathrm{mg} / \mathrm{l}$ & 3.42 & - & SR ISO $6059 / 2008$ \\
\hline & ${ }^{*}$ Alcalinity & $\mathrm{ml} \mathrm{HCl} \mathrm{0,1 \textrm {N }}$ & 0.57 & - & SR ISO 9963-1/1997 \\
\hline & ${ }^{*}$ Temporary hardness & ${ }^{\circ} \mathrm{G}$ & 1.59 & - & SR ISO 9963-1/1997 \\
\hline & ${ }^{*}$ Bicarbonates & $\mathrm{mg} / \mathrm{l}$ & 34.83 & - & SR ISO 9963-1/1997 \\
\hline & ${ }^{*}$ Sulphates & $\mathrm{mg} / \mathrm{l}$ & 8.29 & 250 & Metoda HACH \\
\hline & ${ }^{*}$ Phosphates & $\mathrm{mg} / \mathrm{l}$ & 0.035 & - & SR EN ISO 6878-2008 \\
\hline & $\begin{array}{l}\text { TOC (total organic } \\
\text { compounds) }\end{array}$ & $\mathrm{mg}[\mathrm{C}] / \mathrm{l}$ & 2.45 & - & SR EN 1484/2006 \\
\hline & ${ }^{*}$ Iron & $\mathrm{mg} / \mathrm{l}$ & 0.01 & 0.2 & Kit Merck \\
\hline
\end{tabular}




\section{Statistical data analysis.}

Monofactorial ANOVA was used $(\mathrm{p}<0.05)$. The culture vessel was considered as experimental unit in the comparisons regarding the number of shoots resulted/vessel and the number of standard-sized microcuttings resulted/vessel. For the comparisons regarding plantlet height, multiplication rates (the number of standard-sized microcuttings resulted/plantlet) and proliferation rates (the number of axillary shoots $\geq 2 \mathrm{~cm}$ resulted/plantlet) the plantlet was considered as experimental unit.

\section{RESULTS AND DISCUSSION \\ In vitro multiplication on the standard culture media}

Based on the preliminary tests carried out for the in vitro multiplication stage, we established that the standard multiplication media for apple cultivar 'Royal Gala' should be MSs supplemented with $0.7 \mathrm{mg} / \mathrm{l}$ BAP, which ensures intense proliferation of axillary shoots, while the culture media are simple and low-cost.

One important characteristic of the axillary shoots regenerated in vitro in apple cultivar 'Royal
Gala' was that part of the shoots were over $2 \mathrm{~cm}$ in length (standard sized shoots) and a high number of shoots were under the standard size of $2 \mathrm{~cm}$. Such, after 2 months of culture on MSs $+0.7 \mathrm{mg} / \mathrm{l}$ BAP, from the average number of $162.4 \pm 10.19$ shoots obtained per culture vessel the number of shoots $\geq 2 \mathrm{~cm}$ was $76.6 \pm 7.63$, which represents $47.16 \%$ of the total number of shoots/vessel and the average number of shoots $\geq 2 \mathrm{~cm}$ in length was $85.8 \pm 9.59$. The proliferation rate after two months in culture was $15.32 \pm 1.92$ and the multiplication rate was $19 \pm 2.36$. Multiplication rates were higher than proliferation rates because some shoots could be cut into two standard-sized microcuttings.

The multiplication rates we obtained were higher than the ones reported by other researchers who, for the multiplication of some apple cultivars and rootstocks mostly used PGR combinations consisting of $\mathrm{BA}+\mathrm{IBA}+\mathrm{GA}_{3}$ in various concentrations (Dobránszky and Teixeira da Silva, 2010). Only in cultivar 'Golden Delicious' BA was used as the sole PGR at $1 \mathrm{mg} / \mathrm{l}$, where 4.8 multiplication rates were obtained. Where combinations of PGRs were used, the reported

Tab. 4. The influence of gelling agents upon the number of shoots/vessel and microcuttings/vessel resulted in the multiplication stage in apple cultivar 'Royal Gala'

\begin{tabular}{ccccc}
\hline Treatment & $\begin{array}{c}\text { Total no. of shoots/ } \\
\text { vessel (No. } \pm \text { S.E.) }\end{array}$ & $\begin{array}{c}\text { No. of } \\
\text { shoots/vessel } \\
<2 \mathrm{~cm} \\
\text { (No. } \pm \text { S.E.) }\end{array}$ & $\begin{array}{c}\text { No. of } \\
\text { shoots/vessel } \\
\geq 2 \mathrm{~cm} \\
\text { (No. } \pm \text { S.E.) }\end{array}$ & $\begin{array}{c}\text { No. of } \\
\text { microcuttings/ } \\
\text { vessel } \\
\text { (No. } \pm \text { S.E.) }\end{array}$ \\
\hline Fibrous agar & $92.8 \pm 8.95$ & $34.6 \pm 1.63$ & $57.8 \pm 8.64$ & $74.8 \pm 14.49$ \\
\hline Phytagel + starch & $103.8 \pm 3.39$ & $36.6 \pm 2.08$ & $67.2 \pm 2.72$ & $81.8 \pm 3.81$ \\
\hline Guar gum & $62.6 \pm 8.07^{*}$ & $28.6 \pm 7.02$ & $34 \pm 1.34^{*}$ & $38.2 \pm 1.2^{*}$ \\
\hline Psyllium husk & $77.4 \pm 4.89$ & $27.6 \pm 2.54^{*}$ & $49.8 \pm 3.91$ & $64.8 \pm 7.68$ \\
\hline Phytagel & $64.6 \pm 6.81^{*}$ & $29.2 \pm 3.13$ & $35.4 \pm 6.23$ & $42.6 \pm 6.64$ \\
\hline "Statistically significant differences $(\mathrm{p}<0.05)$ & & &
\end{tabular}

Tab. 5. The influence of gelling agents upon proliferation rates and multiplication rates in apple cultivar 'Royal Gala'

\begin{tabular}{ccc}
\hline Treatment & $\begin{array}{c}\text { Proliferation rate } \\
\text { (No of shoots/plantlet } \pm \text { S.E.) }\end{array}$ & $\begin{array}{c}\text { Multiplication rate } \\
\text { (No. of microcuttings/plantlet } \pm \text { S.E.) }\end{array}$ \\
\hline Fibrous agar & $11.56 \pm 1.28$ & $14.96 . \pm 2.10$ \\
\hline Phytagel + starch & $13.44 \pm 1.22$ & $16.36 \pm 1.34$ \\
\hline Guar gum & $6.8 \pm 0.47^{* *}$ & $7.64 \pm 0.56^{* *}$ \\
\hline Psyllium husk & $9.96 \pm 0.82$ & $12.96 \pm 1.12$ \\
\hline Phytagel & $7.08 \pm 0.88^{* *}$ & $8.52 \pm 1.05^{* *}$ \\
\hline${ }^{* *}$ Differences distinctly significant statistically $(\mathrm{p}<0.01)$ &
\end{tabular}


multiplication rates were lower: in apple cultivar 'Gala' there was $8.0 \pm 2.4$ multiplication rate at PGR concentrations of $4.4 \mu \mathrm{M} \mathrm{BA}+0.5 \mu \mathrm{M}$ IBA $+4 \mu \mathrm{M}$ $\mathrm{GA}_{3}(1+0.1+0.17 \mathrm{mg} / \mathrm{l}$, respectively); in cultivar 'Granny Smith' there was 7.5 proliferation rate generated by the combination of $0.7 \mathrm{mg} / \mathrm{l}$ $\mathrm{BA}+0.1 \mathrm{mg} / \mathrm{l} \mathrm{IBA}$; the highest multiplication rate reported for an apple cultivar was 10.4 in cultivar 'Mutsu' in media containing $1 \mathrm{mg} / \mathrm{l} \mathrm{BA}+0.1 \mathrm{mg} / \mathrm{l}$ IBA.

\section{The influence of alternative gelling agents upon in vitro multiplication in apple cultivar 'Royal Gala'}

From the gelling agents tested, the combination of $0.5 \mathrm{~g} / \mathrm{l}$ phytagel $+50 \mathrm{~g} / \mathrm{l}$ wheat starch gave the best results regarding proliferation rates as well as the quality of axillary shoots regenerated (Tab. 4, Tab. 5). In this treatment, the highest number (103.8) of shoots/vessel was obtained and the highest number of shoots $\geq 2 \mathrm{~cm}$, respectively $67.2 /$ vessel. The values were higher than the ones obtained in the control (media with fibrous agar) but the differences were not significant statistically.

In the treatment containing Phytagel the great majority of plantlets (22 out of 25 ) were hyperhydric, thus we do not recommend the product Phytagel as a gelling agent for the micropropagation of apple cultivar 'Royal Gala'.
The plantlets resulted from the experimental treatments gelled with fibrous agar, Phytagel + starch and Psyllium husk were very vigorous, viable, well-developed.

Dobránszky and Teixeira da Silva (2010) reported that some authors used various natural polymers for apple in vitro multiplication. Such, in apple cultivar 'Marubakaido' guar gum and cassia were tested in combination with $3 \mathrm{~g} / \mathrm{l}$ agar and the proliferation rates were lower as compared to our results obtained in apple cultivar 'Royal Gala' in all the treatments. These were $7.60 \pm 1.45$ in the treatment with agar/guar gum mixture and $6.19 \pm 1.76$ in agar/cassia mixture and the values were similar to the ones obtained in the control treatment gelled with agar $(6 \mathrm{~g} / \mathrm{l})$, where the proliferation rate was $7.16 \pm 1.24$. In other apple cultivars proliferation rates were similar or significantly higher on media gelled with a mixture of cornstarch as compared to the same media gelled with agar. Also, it was reported that in the apple cultivar 'Gale Gala' a higher number of shoots (21.0 - 28.4 shoots) was obtained on media gelled with Phytagel ( $0,25 \%$ concentration) as compared to the media gelled with agar (11.0 - 13.1 shoots).

The substitution of agar with alternative gelling agents can lead to higher proliferation rates and, at the same time, to great cost reductions in

Tab.6. The results regarding in vitro multiplication in apple cultivar 'Royal Gala' on culture media supplemented with meta-topolin, gelled with $50 \mathrm{~g} / \mathrm{l}$ wheat starch

\begin{tabular}{cccccc}
\hline Treatment & $\begin{array}{c}\text { No. of shoots/ } \\
\text { vessel }<2 \mathrm{~cm} \\
(\text { No. } \pm \text { S.E. })\end{array}$ & $\begin{array}{c}\text { No. of shoots/ } \\
\text { vessel }<2 \mathrm{~cm} \\
(\text { No. } \pm \text { S.E.) }\end{array}$ & $\begin{array}{c}\text { Proliferation rate } \\
(\text { No. } \pm \text { S.E. })\end{array}$ & $\begin{array}{c}\text { Percentage (\%) of } \\
\text { shoots/vessel } \geq 2 \\
\text { cm } \\
(\% \pm \text { S.E. })\end{array}$ & $\begin{array}{c}\text { Multiplication } \\
\text { rate } \\
(\text { No. } \pm \text { S.E. })\end{array}$ \\
\hline MSs $+0.7 \mathrm{mg} / \mathrm{lmT}$ & $12.25 \pm 3.59$ & $52.75 \pm 4.58$ & $65 \pm 6.01$ & $81.15 \pm 4.30$ & $76.75 \pm 7.55$ \\
\hline MSs $1 \mathrm{mg} / \mathrm{mT}$ & $53.75 \pm 8.60$ & $62.5 \pm 10.23$ & $116.25 \pm 6.15^{* *}$ & $53.76 \pm 7.72$ & $79.75 \pm 11.68$ \\
\hline${ }^{* *}$ Differences distinctly significant statistically $(\mathrm{p}<0.01)$ & & & &
\end{tabular}

Tab.7. Results regarding the direct ex vitro rooting of the axillary shoots resulted from in vitro cultures on media with various gelling agents in apple cultivar 'Royal Gala'

\begin{tabular}{cccccc}
\hline $\begin{array}{c}\text { Treatment of } \\
\text { origin }\end{array}$ & $\begin{array}{c}\text { Total number of shoots } \\
\text { transferred ex vitro }\end{array}$ & $\begin{array}{c}\text { Rooting } \\
\text { percentage }(\%)\end{array}$ & $\begin{array}{c}\text { Shoot length } \\
(\mathrm{cm} \pm \text { S.E.) }\end{array}$ & $\begin{array}{c}\text { Root clump length } \\
\text { (cm } \pm \text { S.E.) }\end{array}$ & $\begin{array}{c}\text { No. of roots/ } \\
\text { plant (no. } \pm \text { S.E.) }\end{array}$ \\
\hline Phytagel \pm starch & 189 & 98.94 & $3.94 \pm 0.30$ & $4.44 \pm 0.49$ & $13.1 \pm 2.27$ \\
\hline Guar gum & 184 & 99.45 & $2.88 \pm 0.16$ & $6.7 \pm 0.48$ & $14 \pm 2.31$ \\
\hline Starch & 194 & 98.45 & $2.84 \pm 0.19$ & $6.62 \pm 0.94$ & $10.9 \pm 2.05$ \\
\hline Fibrous agar & 181 & 93.92 & $4.1 \pm 0.32$ & $3.67 \pm 0.33$ & $15.4 \pm 2.36$ \\
\hline
\end{tabular}


micropropagation, as these gelling agents are far less costly than agar (Babbar et al, 2005).

The influence of meta-topolin upon the in vitro multiplication of apple cultivar 'Royal Gala'

In the treatment with $1 \mathrm{mg} / \mathrm{l}$ meta-topolin the total number of shoots/vessel was very high as compared to the treatment with $0.7 \mathrm{mg} / \mathrm{l}$ meta-topolin. The percentage of standard-sized shoots of minimum $2 \mathrm{~cm}$ in length was very low as compared to the treatment with $0.7 \mathrm{mg} / \mathrm{l}$ metatopolin and the number of standard-sized shoots/ vessel was similar (Tab. 6). Having in view these results, we recommend the treatment with 1 $\mathrm{mg} / \mathrm{l}$ meta-topolin. Wheat starch proved to be an effective gelling agent, suitable for the in vitro culture of this apple cultivar.

\section{Direct ex vitro rooting}

In the ex vitro rooting and acclimatization experiments we did not use any plant growth regulators for rooting. Direct ex vitro rooting was done in the greenhouse. In the first week we used partial protection by placing plastic trays on top of the rooting tubs. The rooting percentages were high and the root mass was well developed.

From each treatment, ten plants were randomly analyzed in order to establish the average length of root clumps and the number of roots/plant. In all the experimental treatments the length of root clumps was over $3 \mathrm{~cm}$ and the average number of roots/plant was over 10 . In all treatments the rooting percentages were more than $90 \%$; the highest rooting percentage, 99.45 $\%$ was in the shoots harvested from the plantlets cultured on the multiplication media gelled with guar gum and the lowest rooting percentage, $93.92 \%$ was registered in the shoots harvested from plantlets from the in vitro multiplication treatment where fibrous agar was used (Tab. 7).

Although our ex vitro acclimatization method in floating perlite is very simple and does not need facilities for controlled humidity and it uses a very small amount of water, our results are superior to the ones obtained by other authors who used facilities with controled environment and far more complex and expensive substrates: in apple rootstocks 'M.7' and 'MM.106' the survival percentages in greenhouse conditions were $90 \%$ in cocopeat, $0 \%$ in vermicompost/sand $1: 1,20.13$ 5 in sawdust, $21 \%$ in coco-peat/vermicompost $1: 1,25 \%$ in vermicompost, $25.17 \%$ in soil/sand/ perlite 1:1:1, 39.65 in coco-peat/sawdust 1:1, 40.3 $\%$ in coco-peat/perlite $1: 1$ and $50.27 \%$ in soil/ sand/compost 1:1:1 (Modgil et al., 2009, cited by Dobránszki and Teixeira da Silva, 2010).

\section{CONCLUSION}

Our results show that both meta-topolin and BAP are growth regulators suitable for the in vitro multiplication of apple cultivar 'Royal Gala'.

Among the alternative gelling agents we tested, the mixture consisting of Phytagel at 0.5 $\mathrm{g} / \mathrm{l}$ and wheat starch at $50 \mathrm{~g} / \mathrm{l}$ gave the best results regarding in vitro proliferation rate as well as the quality of the shoots that resulted.

In the experimental treatment containing Phytagel as gelling agent the great majority of the plantlets were hyperhydric, thus we do not recommend Phytagel as gelling agent for the micropropagation of apple cultivar 'Royal Gala'.

Direct ex vitro rooting in floating perlite provided very good results, although the method implies neither the use of plant growth regulators for rooting, nor the use of special modern facilities equipped with artificial fog installations.

Acknowledgments. We thank the researchers at the Research Institute Nyiregyháza, especially Judit Dobránszki, Katalin Magyarné-Tábori, Nóra Mendlerné-Drienyovszki and Ildikó Hudák, as well as the rest of their research team, for their help.

\section{REFERENCES}

1. Amiri EM, Elahinia A (2011). Optimization of medium composition for apple rootstocks. African Journal of Biotechnology Vol. 10(18):3594-3601.

2. Awan KH, Khan A, Lodhi MA, Butt SJ (1990). Observation on in Vitro Propagation of M9 Apple Rootstock (Malus sylvestris Mill.). Pak. J. Agri. Sci. 27 (1) 64.

3. Babbar SB, Jain R, Walia N (2005). Guar gum as a gelling agent for plant tissue culture media. In Vitro Cell Dev Biol - Plant, 41:258-261.

4. Bahmani R, Karami O, Gholami M (2009). Influence of Carbon Sources and Their Concentrations on Rooting and Hyperhydricity of Apple Rootstock MM.106. World Applied Sciences Journal 6 (11): 1513-1517.

5. Dalal MA, Das B, Sharma AK, Mir MA, Sounduri AS (2006). In vitro cloning of apple (Malus domestica Borkh) employing forced shoot tip cultures of M9 rootstock. Indian Journal of Biotechnology 5: 543-550.

6. DobránszkyJ,Teixeira da SilvaJA (2010). Micropropagation of apple-a review. Biotechnol Adv 28:462-488. 
7. Fira A, Clapa D, Plopa C (2010). In Vitro Rooting and ExVitro Acclimation in Apple (Malus domestica). Bulletin UASVM Horticulture, 67(1): 480.

8. Iglesias I (2004). Micropropagation and Field Evaluation of the Pear (Pyrus communis L.) 'IGE 2002', A New Selection of the Cultivar Dr. Jules Guyot. Amer. Soc. Hort. Sci. 129(3):389-393.

9. Isutsa DK, Pruts MP, Mudge KW (1998). A Protocol for Rooting and Growing Apple Rootstock Microshoots. Fruit Varieties Journal 52(2):107-116.

10. Kereša $S$, Mihovilović Bošnjak $A$, Barić $M$, Habuš Jerčić I, Šarčević H, Biško A (2012). Efficient Axillary Shoot Proliferation and in Vitro Rooting of Apple cv. 'Topaz'. Not Bot Horti Agrobo 40(1):113-118.

11. Maciel SDC, Voltolini JA, Pedrotti EL (2002). Enraizamento ex vitro e aclimatização do porta-enxerto de macieira marubakaido micropropagado. Rev. Bras. Frutic., Jaboticabal - SP, v. 24, n. 2, p. 289-292.

12. Mert C, Soylu A (2010). Shoot location and collection time effects on meristem tip culture of some apple rootstocks. Pak. J. Bot., 42(1): 549-557.
13. Magyar-Tábori K, Dobránszki J, Jámbor-Benczúr E, Lazányi J, Szalai J (2001). Effects of activated charcoal on rooting of in vitro apple (Malus domestica Borkh.) shoots, Int J Hortic Sci, 7 (2001):98-101.

14. Murashige T, Skoog F (1962). A revised medium for rapid growth and bioassays with tobacco tissue culture. Physiol. Plant 15: 473-497.

15. Pedrotti EL, Voltolini JA (2001). Enraizamento ex vitro e aclimatização do porta-enxerto de macieira M.9. Revista Brasileira de Fruticultura, Jaboticabal, SP, v. 23, n. 2, p. 234-239.

16. Puente J, Marín JA (1992). Splitting of Malus microcuttings enhances rooting. Agronomie, 12:795-797.

17. Soni M, Thakur M, Modgil M (2011). In vitro multiplication of Merton I. 793-An apple rootstock suitable for replantation. Indian Journal of Biotechnology Vol 10: 362368.

18. Zanandrea I, Bacarin MA, Braga EJB, Bianchi V J, Peters JA (2009). Morphological and Physiological Photon Flux Influence Under in vitro Culture of Apple Shoots. Brazilian Archives of Biology and Technology. v.52 n.5:1091-1098. 